\title{
PARASITIC COPEPODS FROM FISHES OF CELEBES AND BORNEO
}

$\operatorname{AUTHOR}(S)$ :

Yamaguti, Satyu

CITATION:

Yamaguti, Satyu. PARASITIC COPEPODS FROM FISHES OF CELEBES AND BORNEO. PUBLICATIONS OF THE SETO MARINE BIOLOGICAL LABORATORY 1954, 3(3): 375-398

\section{ISSUE DATE:}

1954-05-30

URL:

http://hdl.handle.net/2433/174483

RIGHT: 


\title{
PARASITIC COPEPODS FROM FISHES OF CELEBES AND BORNEO
}

\author{
SATYU YAMAGUTI \\ Zoological Institute, Kyoto University, Kyoto
}

With Plates XLIV-XLIX (1-6)

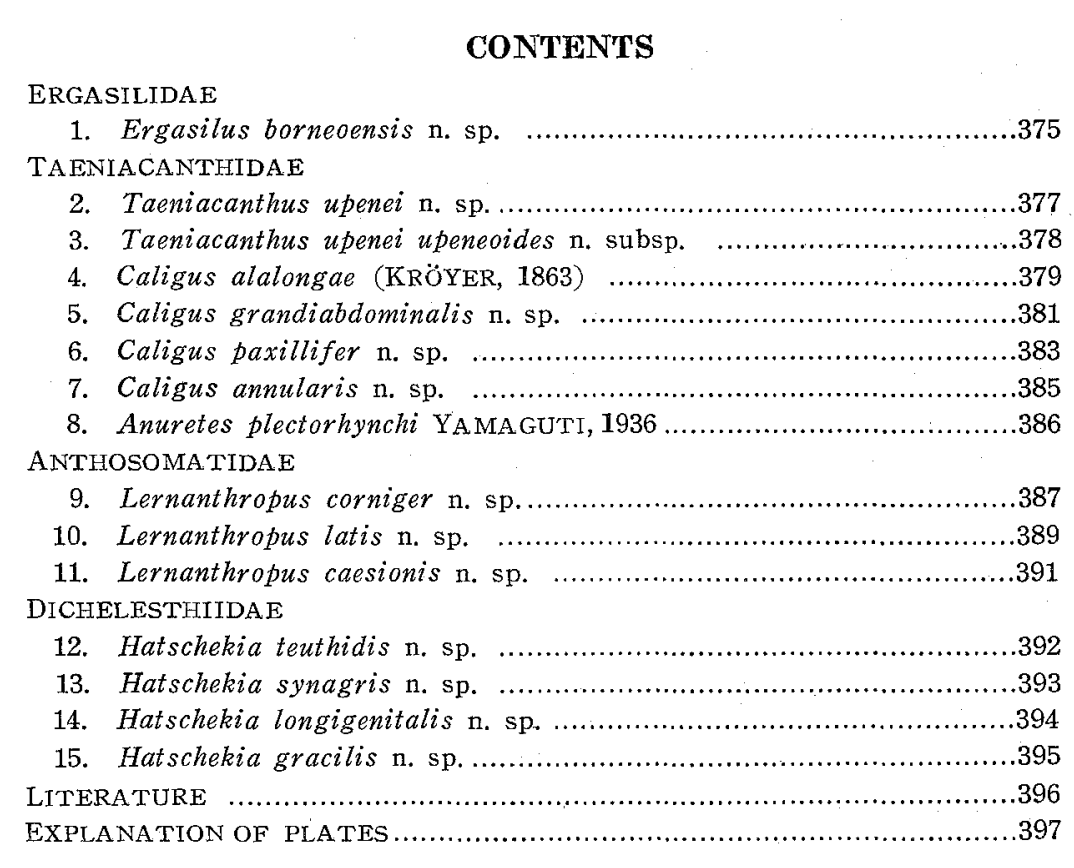

\section{ERGASILIDAE}

1. Ergasilus borneoensis n. sp.

(PI. I, Figs. 1-7)

Habitat and locality. Gill of unknown fish, probably of the Coridae; Bandjermasin, Borneo. Material. Some ten gravid females.

Female. Body $0.9-1.1 \mathrm{~mm}$ long. Head cordate, $0.35-0.38 \mathrm{~mm}$ long by $0.38-0.46$ $\mathrm{mm}$ broad, with a pair of eye-spots, truncated conical in front, well constricted off from first thoracic segment, with which it forms a violin-body $0.55-0.65 \mathrm{~mm}$ long.

Publ. Seto Mar. Biol. Lab., III (3), 1954. (Article 30) 
First thoracic segment as wide as head but a little shorter, truncated or somewhat concave at posterior margin. Second to fourth thoracic segments diminishing regularly in breadth; second and third segments produced backwards into a small rounded lobe at each dorsal posterior corner. Posterior margin of fourth segment almost squarely truncated, covering anterior part of fifth segment. Aprons of second, third and fourth segments fringed with short denticular spines. Genital segment quadrate, 90-100 $\times 100-120 \mu$, without spines on ventral side except along posterior margin which

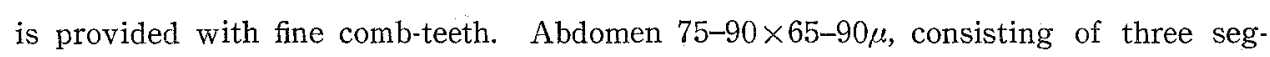
ments of nearly the same length, each of which bears a row of minute spines along the ventral posterior margin. Caudal rami oblong, two-thirds the length of the last two abdominal segments combined, $27-33 \times 21-30 \mu$, with four setae of different length at distal end. Egg strings cylindrical, $0.97-1.0 \mathrm{~mm}$ long by $0.1-0.13 \mathrm{~mm}$ broad.

Appendages. First antenna about $0.15 \mathrm{~mm}$ long, consisting of 6 segments of nearly the same length, with 3 setae at tip. Second antenna 5 -segmented, very long; two distal segments presenting very fine dotted appearance due to striations at right angles to the surface, measuring respectively $0.27 \mathrm{~mm}$ and $0.16 \mathrm{~mm}$ on convex margin in the type. Mandible with two finely pectinated palps and two chitinous processes (terminal and subterminal), each of which bears on one side a row of acicular spines. First maxilla with two setae. Second maxilla covered with spines except on posterior margin. Maxilliped lacking. Rami of first to fourth legs 3-segmented except fourth exopod which is $2-$ segmented. They are armed with spines and setae as follows:

First exopod 1-0, 0-1, 2-5; endopod 0-1, 0-1, 2-4.

Second exopod 1-0, 0-1, 0-6; endopod 0-1, 0-2, 0-5.

Third exopod 1-0, 0-1, 0-6; endopod 0-1, 0-2, 0-5.

Fourth exopod 1-0, 1-5; endopod 0-1, 0-2, 0-4.

Fifth leg uniramose, cylindrical, 2-segmented, with one seta on very short basal segment and two setae on terminal segment.

This species resembles Ergasilus nodosus WILson, 1928 and E. osmeri VAN BENEDEN, 1870, in possessing a very long second antenna and in the head being well constricted off from the first thoracic segment, but differs from WrLson's species in the possession of fifth legs, in the fourth thoracic segment being neither semicircular nor entirely concealing the fifth segment, in the structure of the mandible, in the armature of the legs, etc., and from VAN BENEDEN's species chiefly in the shape of the head. Since no description is given for BENEDEN's species and the original figure leaves much to be desired, a satisfactory comparison is unable to make. 
TAENIACANTHIDAE

\section{Taeniacanthus ubenei $\mathrm{n}$. sp.}

(Pl. I, Figs. 8-10; Pl. III, Fig. 20)

Habitat and locality. Gill of Upeneus sp.; Macassar, Celebes.

Material. About a dozen gravid females. Male unknown.

Female. Body length $0.65-0.74 \mathrm{~mm}$. Cephlothorax subcordate, $0.27-0.31 \mathrm{~mm}$ long by $0.32-0.38 \mathrm{~mm}$ broad with prominent frontal cone, whose apex is rounded and may project but slightly beyond the bases of the first antennae. First thoracic segment fused completely with head. Second to fourth thoracic segments diminishing regularly in size posteriorly, measuring in the type $0.1 \times 0.27 \mathrm{~mm}, 0.084 \times 0.24 \mathrm{~mm}$ and $0.042 \times 0.17 \mathrm{~mm}$ respectively. Genital segment quadrate, $0.066 \times 0.11 \mathrm{~mm}$, forming together with the abdomen a backwardly tapered cylinder. Abdomen 4-segmented; first to fourth segments diminishing in width posteriorly $(96 \mu, 80 \mu, 66 \mu$ and $53 \mu$ respectively in the type), but the third is the shortest of all as shown in the measurements of the type: $40 \mu, 30 \mu, 18 \mu, 27 \mu$. Caudal rami $24 \times 42 \mu$ in the type, with the sides in line with those of the abdomen, armed with setae as usual (one seta on outer margin, another on mediodorsal side, and four at tip). Egg sac cigar-shaped, $0.36-0.4 \times 0.1-0.11 \mathrm{~mm}$, eggs in few longitudinal rows of about a dozen each.

Appendages. First antenna 5-segmented, first to third segments with a continuous row of plumose setae on ventral side, (12 on the first segment except one which is slightly out of the row and an oblique row of 3 smaller setae near the distal end, 6 on the second, 3 on the third); fourth segment with a seta on posterior margin and two ventroterminally, fifth with 7 setae. On the anterior margin of the first antenna there are only 4 setae, 3 on the first segment and one on the second. Second antenna 2-segmented; proximal segment longer than the distal, which bears three simple and two pectinate claws; comb extending along the posterior border of the terminal segment for its greater part. Maxillary hook falciform, pointed. Mandible with a small pointed accessory at base of terminal blade. First maxilla nodular, with 4 whip-like setae of different length. Second maxilla terminating in a very small spiniform palp. Maxilliped reduced to a blunt conical process bearing a tuft of three backwardly directed setae at inner end of its base. Between the second maxillae and the maxillipeds there is seen a stout chitinous bar denticulated along its anterior border, with a small elliptical chitinous knob just in front of its outer end. Behind this bar lie in the median line two inverted V-shaped chitinous structures one behind the other (Fig. 20); the posterior one is followed by another elongated $\mathrm{V}$-shaped chitinous structure, thus forming a rhomb, the posterior end of which is enlarged laterally and extends as far backward as the base of the first pair of legs, 
Exopod of first leg 2-segmented; distal segment with one setiform spine and 6 plumose setae along its free margin; proximal segment with a plumose seta at outer corner; endopod with 2 setiform spines and 8 marginal setae. Rami of second to fourth legs 3 -segmented, armed with spines and setae as follows:

Second exopod 1-0, 1-1, 2-5; endopod 0-1, 0-2, 3-3.

Third exopod 1-0, 1-1, 2-6; endopod 0-1, 0-2, 3-2.

Fourth exopod 1-0, 1-1, 2-6; endopod $0-1,0-1,2-2$.

The spines on all the exopods of the second to fourth legs look like setae, so that they may well be looked upon as such. Fifth leg uniramose, 2-segmented; basal segment short, with one seta dorsally, terminal segment about $60 \mu$ long by $42 \mu$ broad, with three setae distally besides a setiform spine and a comb of stiff hairs on inner margin.

This species differs from the most closely related Taeniacanthus neopercis YAMAGUTI, 1939, in the body size, the structure of the maxilliped, the armature of the swimming legs, etc.

\section{Taeniacanthus upenei upeneoides n. subsp.}

(P1. II, Figs. 17-18)

Habitat and locality. Gill of Upeneoides bensasi (TEMM. et SCHLEG.); Macassar; Celebes. Material. Two gravid females, male unknown.

Female. Body length $0.65-0.75 \mathrm{~mm}$, cephalothorax subcordate, $0.27-0.3 \mathrm{~mm}$ long by $0.28-0.33 \mathrm{~mm}$ broad, with flattened frontal cone, whose anterior margin in the same convex line as that of first antenna. First thoracic segment fused completely with head. Second to fourth segment decreasing regularly in length and breadth. Genital segment quadrate, $60 \times 100 \mu$, forming with abdomen a slightly telescoping cylinder. Abdomen $120 \mu$ long, 4-segmented; first to fourth segments of type measuring $33 \times 84 \mu$, $27 \times 75 \mu, 18 \times 66 \mu$ and $30 \times 60 \mu$ respectively, third segment being the shortest of all. Caudal rami $24 \times 24 \mu$, each with 6 setae (one on dorsolateral margin, another on mediodorsal side, and four at tip). Egg sac plump, $0.36 \times 0.15 \mathrm{~mm}$, eggs (except the terminal) arranged in 4 longitudinal rows of 8 each.

Appendages. First antenna 5-segmented; first to third segments with a continuous row of plumose setae (13 on the first, 6 on the second, 1 on the third). Besides these there are an oblique row of 3 setae on the ventral side of the first segment near its distal end and two on the anterior border of the same segment, a similar one at the middle of the anterior margin of the second segment, another at the posterior distal corner of the third segment. Fourth segment with a seta on posterior margin and two close together ventroterminally, fifth with 7 setae. Second 
antenna 2-segmented, distal segment a little shorter than the proximal, with 3 simple and 2 pectinate claws, one of which does not curve at the tip like the other, with the comb extending along the posterior border of the terminal segment, and a double row of teeth at its proximal end. Maxillary hook falciform, $130-135 \mu$ long. Mandible with a small pointed accessory alongside terminal blade. First maxilla nodular, with 3 setae of different length. Second maxilla with a minute spiniform palp at base of its pectinate terminal blade. Maxilliped reduced to a blunt conical process, with a minute on inner margin near its apex and a tuft of two backwardly directed setae at inner end of its base. Between the second maxillae and the maxillipeds there is a chitinous bar finely denticulated along its anterior border, with a small chitinous knob just in front of its outer end. Behind this bar is seen a chitinous structure as shown in P1. II, Fig. 17.

Exopod of first leg with 8 plumose marginal setae, one of which is rudimentary and another is devoid of hairs on the inner side; endopod with 8 plumose setae on terminal segment, two on the middle segment, and one on the basal segment. Rami of second to fourth legs 3 -segmented, armed with spines and setae as follows:

Second exopod 1-0, 1-1, 2-6; endopod 0-1, 0-2, 3-3.

Third exopod 1-0, 1-1, 2-6; endopod 0-1, 0-2, 2-3.

Fourth exopod 1-0, 1-1, 2-6; endopod 0-1, 0-1, 2-2.

The spines on all the exopods of the above legs are small and bear rudimentary hairs, so that they may well be regarded as setae, while those on the endopods are typical. Fifth leg uniramose, 2-segmented; basal segment with one seta dorsolaterally, terminal segment rounded or spatulate, $42 \mu$ wide, with 3 setae and one setiform spine distally.

This subspecies resembles Taeniacanthus upenei so closely that a very careful comparison is needed. The most remarkable differences are found in the chitinous median structure on the ventral surface of the cephalothorax in front of the base of the first pair of legs in the shape of the terminal segment of the fifth leg and in the absence of stiff hairs on the inner margin of this segment.

There are some other differences in the armature of the legs, especially of the first leg.

\section{Caligus alalongae (KRÖYER, 1863)}

(P1. II, Fig. 19; P1. III, Fig. 21)

Habitat and locality. Gill of Elagatis sp. and Caranx sp.; Macassar, Celebes.

Material. 5 females and 5 males, all mature.

Female. Body length $2.65-3.2 \mathrm{~mm}$. Carapace $1.3-1.45 \mathrm{~mm}$ in length, $1.3-1.45 \mathrm{~mm}$ 
in width excluding marginal membrane, with rounded sides and distinct frontal plate, truncated behind; medial lobe more than a third of width of carapace, with its lateral corners in close contact with, or overlapping, inner processes of lateral lobes, forming complete oval sinus between. Lunules $0.13-0.15 \mathrm{~mm}$ in diameter, $0.27-0.34$ $\mathrm{mm}$ apart from each other. Free thoracic segment $0.25-0.3 \mathrm{~mm}$ in length. Genital segment $0.96-1.33 \mathrm{~mm}$ in length (including its anterior portion which is well constricted off ), 0.72-1.0 mm wide, produced backwards into distinct lobes on either side of base of abdomen. Abdomen 0.25-0.27 $\times 0.28-0.4 \mathrm{~mm}$. Caudal rami small, attached to abdomen subterminally on its ventral side, with 5 setae, three of which are terminal; one is at the posteromedial corner and another at the posterolateral corner. Egg strings about $1.3 \mathrm{~mm}$ long, containing 16 eggs.

Appendages of female. First antenna 2-segmented; proximal segment beset along its anteroventral margin with two rows of plumose setae; distal segment rodshaped, tipped with 11 minute setae. Second antenna with long, simple, terminal claw. Mandible with about a dozen comb-like teeth. Maxillary hook provided at base with a pointed tooth-like accessory spine along with two minute papillae bearing extremely fine setae. Maxilla bifurcate, the anterior ramus much smaller; basal semicircular, chitinous plate with a nodular process on the convex side and another on the flat side, just in front of which and behind the double maxillary palp lies a small, elliptical, transversely striated pad simulating a sucker. Distal segment of first maxilliped with an auricular fold, its terminal claws with a narrow lateral flange, which is smooth in the larger claw but pectinate in the smaller claw. Basal segment of second maxilliped with two small shelf-like projections on inner side as pointed out by KIRTISINGHE, terminal claw with a setiform spine on inner side. Furca with two pointed prongs which are covered on the outer side with an extremely finely corrugated cuticle, and the distal portions of which are parallel or even slightly convergent to each other.

Of the three terminal spines of the first leg the outer one is simple but the other two bear each a small accessory spine at the claw-like tip. On the inner margin there are four setae, of which the distal one is simple and rather spine-like, but the other three are plumose. Basipod and middle segment as described by KIRTISINGIEE. Second leg biramous, both rami three-segmented, armed with spines and setae as follows: Exopod 1-1, 1-1, 1-7; endopod 0-1, 0-2, 0-6. The confluent basal plate of third legs $0.72-0.93 \mathrm{~mm}$ wide, covering bases of fourth legs on their ventral side, provided on the ventral side near the median line with an anterior group of 9 to 12 small pointed teeth and a stronger posterior chitinous tooth bifurcated to the base, and from the base of the marginal hook toward the posterior sinus of the cephalothorax extends an oblique row of 14 to 20 minute pointed teeth. 
Marginal hook at the base of the exopod of the third leg with a very narrow flange at its distal portion. Between this hook and the base of the endopod extends an apron-like membrane attached to the margin of the basal plate of the third leg and fringed with hairs along its emarginate free margin. Exopod of third leg not jointed, though two slight constrictions suggestive of segmentation may be recognizable, with four simple setae and five plumose setae, endopod distinctly two-segmented, proximal segment with one long plumose seta, distal segment with 6 plumose setae diminishing in size outwards. Fourth leg 4-segmented; of the three terminal spines two are pectinate like that of the second or the third segment, but the other is smooth. Fifth leg represented by a minute seta with a papilliform base; sixth leg represented by a tuft of three similar setae, two of which have a common papilliform base. Both pairs of legs are a little medial to the posterior lateral margin of the genital segment just in front of the point where the egg strings are attached.

Male. Body length $1.5-2.2 \mathrm{~mm}$. Carapace $1.1-1.38 \times 1.07-1.38 \mathrm{~mm}$, lunules $0.12-$ $0.16 \mathrm{~mm}$ in diameter, $0.25-0.3 \mathrm{~mm}$ apart from each other. Free thoracic segment $0.175-0.25 \times 0.26-0.3 \mathrm{~mm}$, with a small nodular projection on each side just behind the larger lateral prominence, on the ventral side of which the fourth leg arises. Between this projection and the genital ovate or flask-shaped, 0.37-0.46 $\times 0.3-0.44 \mathrm{~mm}$, only slightly notched on lateral margin immediately behind sixth leg, separated from abdomen by a distinct notch on lateral margin immediately behind sixth leg, separated from abdomen by a distinct notch on lateral margin; posterior margin widely incised at the center on the dorsal side, but divided on the ventral side into two symmetrical lobes separated by a distance of $30-60 \mu$. Abdomen with convex or sloping sides, $0.11-0.16 \mathrm{~mm}$ long on lateral margin, $0.2-0.325 \mathrm{~mm}$ in maximum width. Caudal rami attached to abdomen terminally, armed as in female, though the seta at the posteromedial corner is much smaller and inconspicuous.

Appendages of male. Like those of female except that the second antenna has a shorter terminal claw and that each posterolateral corner of the genital segment bears two minute setae close together representing the rudiment of the seventh leg.

The account given above agrees well in essential particulars with KIRTISINGHE's description based on the material from Ceylon.

\section{Caligus grandiabdominalis n. sp.}

(Pl. III, Figs. 22-25)

Habitat and locality. Gill of Caesio kuning (Cuv. et VALENC.); Macassar, Celebes. Material. Two mature females only.

Female. Body length $2.2-2.32 \mathrm{~mm}$. Carapace rounded, $0.68-0.75 \times 0.75-0.8 \mathrm{~mm}$, 
with very prominent frontal plate; medial lobe much more than half the width of the carapace with arcuate posterior margin; posterior sinus gaping; lateral lobes comparatively small, with lateral borders turned over ventrally, pointed posteriorly, projecting as far back as medial lobe. Lunules about $0.1 \mathrm{~mm}$ in diameter, 0.09-1.0 $\mathrm{mm}$ apart from each other. Free thoracic segment short, strongly constricted at both ends, $0.23-0.25 \mathrm{~mm}$ wide, covered dorsally by genital segment for half its length. Genital segment rounded quadrangular, $0.67-0.75 \times 0.94-0.97 \mathrm{~mm}$, with a more or less conspicuous notch at middle of anterior border, lateral margin produced backwards into a rounded lobe, posterior end depressed toward the middle, to which the unusually large abdomen is attached by a short neck. Abdomen one-segmented but clearly divided into two portions; anterior portion flattened peach-shaped, $0.6-0.7 \times 0.7-0.84$ $\mathrm{mm}$, with narrow sinus between itself and genital segment, posterior corners rounded; posterior portion quadrate, $0.1-0.125 \times 0.225 \mathrm{~mm}$. Caudal rami small, approximately quadrate, each with 3 spiniform setae at posterior end and two much smaller setae at posterolateral corner. Egg sac plump, 0.55-0.6 $\times 0.25-0.26 \mathrm{~mm}$, containing 8-9 eggs, attached to ventral side of genital segment close to posterior end nearer to median line than to lateral borders.

Appendages. Basal segment of first antenna $108-111 \mu$ long by $57-60 \mu$ wide, beset ventrally with over 20 plumose setae; terminal segment rod-shaped, 90-96 $\mu$ long by $20-24 \mu$ wide, with 1 subterminal and 11 terminal setae. Second antenna weakly developed; terminal claw bent at right angles near its tip. Maxillary hook consisting of a simple, lightly curved, backwardly pointing spine. Maxilla forming a small, simple, broad-based rod; maxillary palp terminating in a single seta. Mandible with about a dozen minute teeth. First maxilliped with wing-like fold near the base of terminal claws, both of which are pectinate. Basal segment of second maxilliped very stout, terminal claw practically smooth, curved at right angles at about its middle. Furca lacking. Terminal segment of first leg with three setae on inner margin, and one seta and three spines at end, one of the latter simple but the other two bifid at tip as usual. Both rami of second leg 3-segmented, armed with spines and setae as follows: Exopod 1-1, 1-1, 1-6; endopod 0-1,0-2, c-6. The middle segment of the endopod bears on the outer margin a row of 10-11 short backwardly pointing spines, whose broad bases are held together by a membrane. The distal end of this outer margin is produced into a prominent cone directed outward and backward. Expanded common base of third legs without special armature; exopod may or may not be 2-segmented, with 6 or 7 setae on distal segment; basal hook with an only slightly curved blade $32-36 \mu$ long by $12 \mu$ broad. Apron between this hook and the endopod is not emarginate at its free border. Endopod with a long stout seta on proximal segment and 6 setae on distal segment. 
The two terminal segments being fused, the fourth leg is 3-segmented, though there are 5 spines as usual at their respective position; the narrow lateral flanges of these spines are not pectinate. On the ventral side of each posterior lobes of the genital segment there are two fine setae representing the fifth and sixth leg respectively, the outer one is single, but the inner one is double and lies only a little more anteriorly.

This species is characterized by the possession of an unusually large abdomen, hence the specific name. It is to be noted that the furca is entirely absent in the species under consideration.

\section{Caligus paxillifer ${ }^{1)}$ n. sp.}

(P1. III, Figs. 26-27 ; P1. IV, Figs. 28-32)

Habitat and locality. Gill of Chorinemus moadetta (Cuv. et VALENC.); Macassar, Celebes. Material. A single mature female.

Female. Body $2.85 \mathrm{~mm}$ long. Carapace orbicular, $1.35 \times 1.3 \mathrm{~mm}$, with prominent frontal plate which is deeply incised at the center, Lunules large, $0.21 \mathrm{~mm}$ in diameter, $0.2 \mathrm{~mm}$ apart from each other. Eye-spots about $0.4 \mathrm{~mm}$ from frontal margin. Dorsal chitinous frame-work of carapace H-shaped with divergent arms but not in the shape of a double $\mathrm{H}$ as shown by WILSON for Caligus haemulonis, to which the present species is most closely related; a pair of acicular chitinous ribs extending from beside eye-spots to lunules. Median lobe of carapace with rounded corners, just half the breadth of carapace at base, reaching about $0.1 \mathrm{~mm}$ further back of lateral lobes which have rounded ends; posterior sinus moderately deep. Free thoracic segment $0.15 \mathrm{~mm}$ long by $0.37 \mathrm{~mm}$ broad, with prominent sides. Genital segment orbicular, $0.8 \times 0.875 \mathrm{~mm}$, with its anterior end somewhat constricted off in form of a ring; abdomen apparently one-segmented, subcylindrical, $0.5 \times 0.275$ $\mathrm{mm}$, posterior half distinctly broader than anterior half. A very faint segmentation line is seen on the ventral side between these two portions. Caudal rami $104 \times 78 \mu$, somewhat convergent posteriorly, each with 6 plumose setae, of which the one at the inner corner and the two at the outer corner are much smaller than the others. Eggs about $0.2 \mathrm{~mm}$ in diameter; their number as well as length of egg sac unknown.

Appendages. Proximal segment of first antenna about as long as distal segment, with numerous comparatively short plumose setae along anteroventral margin; distal segment cylindrical, $0.12 \mathrm{~mm}$ long by $30 \mu$ broad, with a dozen setae at tip and another on posterior margin near tip. Second antenna with a stout blunt-pointed spine behind its base; terminal claw bent at right angles. Maxillary hook large, curved at right angles, with an accessory spine on the line connecting its base and

1) The specific name refers to the peg (paxillus) observed on either side of the furca. 
that of the maxillary palp nearer to itself. Behind the base of this hook is a minute setiferous papilla similar to those on the base. Maxilla represented by a stout, not acuminate, slightly curved, chitinous process with a triangular base, reaching to tip of proboscis; maxillary palp rod-shaped, tipped with two simple setae, one of which is very fine. Mandible with 12 sharp teeth. First maxilliped with an auricular fold near its terminal claws which have on either side a finely pectinnated flange. Distal segment of second maxilliped about half as long as proximal segment, with an accessory setiform spine on concave side as usual. The base of the furca is oval though somewhat pointed in front and measures $90 \mu$ by $60 \mu$, enclosing a large elliptical foramen; branches comparatively long $(90-96 \mu)$, slightly divergent, but their rather blunt tips are gently curved inwards, the space between them being $60 \%$ in width. On either side of the base of the furca there is a small chitinous peg projecting ventrad perpendicularly.

Basal segment of first leg with a stumpy process representing the rudiment of an endopod at distal end of posterior margin, middle segment pectinate along posterior margin; distal segment with a seta and three two-tipped claws of different length at distal end but no setae on inner margin. Rami of second and third legs armed with spines and setae as follows:

Second exopod 1-1, 1-1, 1-7; endopod 0-1, 0-2, 0-6.

Third exopod 1-1, 3-4; endopod 0-1, 0-6.

The outermost seta on the terminal segment of the second exopod is short and has a flange on the inner side, and the next one is a little longer and plumose on the inner side only, while the others are all much longer and plumose on both sides. The hook at the base of the third exopod looks as if it were jointed near its base, this terminal portion measuring $54-60 \mu$ along the convex margin. Fourth leg made up of three segments; first segment longer than the others combined; second with one terminal spine, third decidedly longer than second, with three spines at distal end and another on posterior margin. The fifth leg, not visible in dorsal view, consists of three minute plumose setae situated close together on the posterolateral margin of the genital segment; the inner two setae have a common base.

This species is characterized by the absence of setae on the inner margin of the terminal segment of the first leg, by the presence of an accessory spine for the maxillary hook, and the possession of a peg on either side of the furca. It agrees with C. haemulonis KRÖYER in general appearance, body size, unsegmented abdomen, absence of plumose setae on the posterior border of the terminal segment of the first leg, and the 3-jointed fourth leg, but differs from it in the frontal plate not projecting so strongly, and in the lunules being separated only by their own diameter. 
Wilson says that in $C$. haemulonis the basal joint of the fourth leg is as long as both the others, and the second and third joints are of the same length with all the claws quite close together, and illustrated the base of the furca in his Platefigure 182 as having parallel sides and a truncate end. This is not the case with the present species. Further, no mention is made of the presence of an accessory spine for the maxillary hook ("first maxilla" of WILSON) nor of a peg on either side of the furca.

C. chorinemi KRÖYER is stated; according to WILSON's key, to have a broad acorn-shaped genital segment with fifth legs visible in dorsal view, and a two-jointed abdomen, whose basal joint is three times the terminal.

\section{Caligus annularis n. sp.}

(Pl. IV, Figs. 33-34)

Habitat and locality. Gill of Otolithes sp. and Caranx sp.; Macassar, Celebes. Material. 2 mature females.

Female. Body 2.1-2.4 $\mathrm{mm}$ long. Carapace orbicular, $0.9-1.0 \mathrm{~mm}$ in length, 0.95$1.04 \mathrm{~mm}$ in maximum width near posterior end frontal plate prominent, with a deep median incision; lunules $0.18 \mathrm{~mm}$ in diameter, $0.1-0.13 \mathrm{~mm}$ apart from each other. Dorsal chitinous framework $\mathrm{H}$-shaped, with divergent arms. A pair of acicular ribs present in cephalic area. Median lobe broadly rounded behind, projecting but little back of laterial lobes, about half as wide as the carapace at its base; posterior sinus triangular; lateral lobes with rounded ends. Free thoracic segment $0.125 \mathrm{~mm}$ long, 0.25-0.26 mm broad through fourth legs. Genital segment acorn-shaped, $0.71-0.83 \mathrm{~mm}$ long by $0.6-0.74 \mathrm{~mm}$ broad, its anterior portion distinctly constricted off as a ring. Abdomen cylindrical, arising from posterodorsal side of genital segment, 0.4-0.45 mm long by $0.2-0.23 \mathrm{~mm}$ broad, unsegmented. Caudal rami $66-75 \times 48-60 \mu$, each with 7 setae, of which the three terminal are the longest and the two subterminal are on the outer margin, the other two are rudimentary and lie at the inner posterior corner. Egg sacs $0.25 \mathrm{~mm}$ in diameter.

Appendages. Proximal segment of first antenna nearly triangular, about $90 \mu$ long by $60 \mu$ broad, covered ventrally for its proximal half by the lateral lobe of the frontal plate, which bears dorsally a submarginal row of hairs; distal half well provided with setae; distal segment cylindrical, $70-80 \mu$ by $27 \mu$, with 13 setae at tip and another on distal posterior margin. Second antenna 2-segmented; terminal claw curved at right angles, with a fine, setiform, ventral spine near its base. Behind the base of the second antenna is a blunt, not strongly chitinized spine $38-48 \mu$ long by $18-21 \mu$ broad. Maxillary hook just like terminal claw of second antenna, though 
smaller $(0.15 \mathrm{~mm}: 0.1-0.15 \mathrm{~mm}$ as measured from base to tip along convex margin), with an accessory spine medial to its base. Maxilla in form of a stout, blunt-pointed process, only slightly curved outward; palp terminating in two setae, one of which is rudimentary. First and second maxillipeds in the usual form, though the proximal segment of the former is comparatively thick. Furca $105-126 \mu$ long from anterior end of its base to tip of branch; base rounded in front, $54-70 \mu$ in diameter; branches curved inward, with rather blunt tip, 50-66 $\mu$ long, $70-75 \mu$ from side to side. Neither peg nor anything alike on either side of furca. First leg without setae on posterior margin of terminal segment as in Caligus paxillifer; terminal claws $33 \mu, 27 \mu$ and $21 \mu$ long respectively. Second and third legs armed with spines and setae as follows:

Second exopod 1-1, 1-1, 1-7; endopod 0-1, 0-2, 0-6.

Third exopod 1-1, 3-4; endopod 0-1, 0-6.

Basal hook of third leg 2-segmented; distal segment 30-36 $\mu$ long. Fourth leg 3-segmented; first segment as long as second and third segments combined; second segment $90-100 \mu$ long; third segment $0.1-0.14 \mathrm{~mm}$ long, with four spines. Fifth leg invisible in dorsal view, made up of a tuft of three setae, two of which have a common base, situated ventrally near posterolateral corner of genital segment.

This species agrees well with Caligus paxillifer in the armature of the swimming legs, but differs from it in the anterior portion of the genital segment being distinctly marked off as a ring, in the genital segment being acorn-shaped instead of being orbicular, in the abdomen being unsegmented, in the absence of a pair of pegs beside the furca, in the shape and size of the furca, etc.

The specific name refers to the ring of the genital segment.

\section{Anuretes plectorhynchi YAMAGUTI, 1936}

Habitat and locality. Gill of Plectorhynchus sp.;. Macassar, Celebes. Material. About a dozen mature females.

Female. Body 1.3-1.7 mm long. Carapace orbicular, $0.95-1.05 \mathrm{~mm}$ long by $0.95-$ $1.04 \mathrm{~mm}$ wide behind its middle; thoracic area quadrangular; median lobe $0.45-0.51$ $\mathrm{mm}$ wide, a little more, or less than, or equal to, half the breadth of carapace, with its posterior margin level with blunt tips of lateral lobes or slightly further behind, usually in contact with anterior margin of genital segment; lateral area narrow, frontal plate well defined. Free thoracic segment $0.09-0.15 \times 0.15-0.25 \mathrm{~mm}$, not visible from dorsal side unless the body is stretched. Genital segment rounded, 0.41-0.52 $\times 0.7-0.73 \mathrm{~mm}$. Abdomen fused with genital segment leaving two-lobed anal region free, which lies on the posterodorsal side of the genital segment. Caudal rami stumpy, $20-27 \mu$ broad, with 6 setae. Egg sac plump, $0.7-0.95 \times 0.22-0.25 \mathrm{~mm}$, containing a 
series of $10-20$ eggs.

Appendages. Just as described in my paper of 1936.

\section{ANTHOSOMATIDAE}

\section{Lernanthropus corniger $\mathrm{n}$. sp.}

(Pl. IV, Figs. 35-39; Pl. V, Figs. 40-41)

Habitat and locality. Gill of Megalaspis sp.; Macassar, Celebes.

Material. A single mature female.

Female. Body oblong, $2.7 \mathrm{~mm}$ long. Head ovate, $1.15 \mathrm{~mm}$ long by $1.0 \mathrm{~mm}$ wide; lateral margins turned ventrally and approaching each other, projecting forward in the form of a sleeve $0.275 \mathrm{~mm}$ further anteriorly than frontal margin which is somewhat depressed at the center; posterior margin notched; antennal area with a stout coathanger-shaped chitinous bar about $0.45 \mathrm{~mm}$ long. First thoracic segment $0.15 \times 0.475 \mathrm{~mm}$, constricted off from head and second segment, almost entirely concealed in dorsal view. Second segment forming prominent rounded shoulder of the trunk, $0.775 \mathrm{~mm}$ in diameter, fused with third segment with a shallow lateral notch indicating the separation of the two segments. Third segment $0.54 \mathrm{~mm}$ long by 1.0 mm wide, with convex sides, constricted off from dorsal plate of fourth segment. Latter circular, $0.75 \times 0.91 \mathrm{~mm}$. Fourth segment showing ventrally a distinct ovate plate $0.61 \mathrm{~mm}$ long by $0.48 \mathrm{~mm}$ wide, with the sides pressed against the third legs. Fifth segment short, without appendages. Genital segment $0.15 \mathrm{~mm}$ long, with convex sides, narrowed abruptly behind; abdomen vase-shaped, $0.12 \mathrm{~mm}$ long by $144 \%$ wide, entirely concealed in dorsal view. Caudal rami horn-shaped, $0.135-0.15 \times 0.045 \mathrm{~mm}$, somewhat divergent, projecting behind dorsal plate for greater part of their length, each with two minute spiniform setae at distal end and another on lateral margin. Egg strings unknown.

Appendages. First antenna 6-segmented, tapering distally, with few short setae on anterior margin besides one subterminal and several terminal ones. Just in front of the base of each second antenna is seen a simple seta projecting backward and inward from an elevation of the head; it probably represents an antennule. Second antennae 2-segmented, with a pair of $\mathrm{V}$-shaped chitin pieces appressed to each other between their bases; segments presenting fine dots all over except on the comparatively short, longitudinally striated terminal claw as well as on the knob lying opposite the concave side of this claw. On the inner side of the distal segment there is a rudimentary spine with a mamillary base destitute of dots. Between this spine and the knob mentioned above is a marked rise and fall of the margin. Mandible slender, 
without teeth. Maxilla divided into two rami ; inner ramus nodular, situated immediately beside proboscis, tipped with two spines, outer ramus directed outwards tapering toward distal end with two spines of unequal length, covered on the ventral surface with very fine spines, of which those on the distal half of the ramus are much smaller than those on the proximal half and only discernible with the aid of an oil immersion lens. The longer terminal spine of this ramus shows a slight bending at the middle as if it were jointed; the terminal portion contains a skeletal chitin for its proximal half only, so that the distal half looks like a seta. The same is true with the shorter spine. First maxilliped 3-segmented; basal segment comparatively stout, as long as the remaining or even longer. Middle segment with nine, slightly recurved, dentiform spines on the distal inner surface, and another a little larger one on the distal dorsal side; terminal segment forming a short typical claw which measures about $45 \mu$ on its concave margin and carries along each side a row of six spines diminishing in size distally, leaving the point free. Second maxilliped 4-segmented; second segment stouter than first, longer than third and fourth combined, with a minute seta on inner margin opposite terminal claw, covered on ventral side with extremely fine spines scarcely projecting above the surface except those around the seta mentioned above; third segment likewise spined, fourth segment forming a well chitinized powerful claw with a few transverse striations on proximal convex side.

First leg biramose, with a seta medial to its base, concealed beneath second maxilliped; outer ramus carpus-shaped, with a row of 5 spines at distal end, covered with very small spines on outer face; inner ramus rod-shaped, covered with comparatively few spinelets, terminating in a seta which is plumose except for the basal portion. Second leg biramose, with a simple seta lateral to its base; outer ramus spined like that of first leg, but one of the marginal spines (the second one as numbered from outside) lies a little out of the row and appears rudimentary, inner ramus rod-shaped, without seta, a little longer than outer ramus, covered with spinelets. Third legs plicate, entirely separated one from the other, reaching backward to level of bases of fourth legs, showing outer skirt in dorsal view, with inner margin pressed against ventral plate of fourth segment. Fourth legs divergent, each divided under dorsal plate into two rami each tapering to a pointed tip; outer ramus measuring $1.06-1.075 \times 0.2 \mathrm{~mm}$, inner one $0.875-0.925 \times 0.15-0.175 \mathrm{~mm}$.

This species bears a certain resemblance to Lernanthropus spiculatus WiLson, 1913, in general appearance, but differs from it in the head lacking the lateral notch indicating the separation of the antennal area from the rest of the head and possessing more prominent anterior horns, in the dorsal plate of the fourth segment being circular instead of ovate, in the presence of a distinct ventral plate for the fourth thoracic 
segment, in the outer skirt of the third legs and the greater part of the caudal rami being visible in dorsal view. As regards the appendages there are marked differences between the two species, especially in the structure of the antennae, of the maxillipeds (WILson seems to have overlooked the first maxilliped) and of the legs. In Wilson's species the first legs are rudimentary, and the second are reduced to mere knobs, while the third are fused at the base in the midline in strong contrast with those of the present species.

The specific name refers to the horn-like anterior lobes of the head.

\section{Lernanthropus latis n. sp.}

(Pl. V, Figs. 42-48)

Habitat and locality. Gill of Lates calcarifer BLOCH; Macassar, Celebes.

Material. 5 males and 12 females, all mature.

Female. Body length (from anterior extremity to tips of caudal rami exclusive of fourth legs) $4.2-4.6 \mathrm{~mm}$. Cephalothorax rounded quadrangular with the greatest breadth behind its middle, $0.7-0.75 \times 0.7-0.8 \mathrm{~mm}$, with an invagination at each anterolateral corner, just in front of which are seen from the dorsal side the first antenna and the base of the antennule. The first thoracic segment is usually fused with the head, but occasionally constricted from it as well as from the second thoracic segment, measuring $0.18-0.2 \mathrm{~mm}$ in length and $0.35-0.4 \mathrm{~mm}$ in breadth. Second and third thoracic segments with convex sides, well marked off, measuring $0.5-0.63 \times 0.55-0.82$ $\mathrm{mm}$ and $0.85-1.05 \times 0.7-1.0 \mathrm{~mm}$ respectively. Fourth legs to caudal rami entirely covered up by dorsal plate, which is oval with maximum breadth of $1.3-1.6 \mathrm{~mm}$, and more or less distinctly truncated at the posterior margin, forming a violin-shape together with third thoracic segment. As measured from the posterior end of the third thoracic segment the dorsal plate is $2.1-2.4 \mathrm{~mm}$ long. In the type the genital segment bearing the fifth legs is $0.3 \mathrm{~mm}$ long and $0.4 \mathrm{~mm}$ broad at the level where the egg strings are attached.

Abdomen small, quadrate, with lightly convex sides. Caudal rami horn-shaped, divergent posteriorly, attached to abdomen terminally, $0.15-0.24 \mathrm{~mm}$ long, $75-90 \mu$ broad at the base which bears two setae dorsally. Egg string $2-4 \mathrm{~mm}$ long by $0.2-$ $0.23 \mathrm{~mm}$ broad, containing a series of $32-82$ discoid eggs. The spermatophore attached to the genital segment behind the egg string is $0.11-0.16 \mathrm{~mm}$ long.

Appendages of female. First antenna distinctly 6-segmented, tipped with several minute setae. Second antenna with stout, conical, chitinous tooth about $60 \mu$ long and a small, papilliform chitinous projection tipped with a very fine spine on inner 
side of basal segment; terminal claw with very fine longitudinal striae on the surface except on the convex side where extremely fine granulations are scattered. Mouth tube tapering distally. Mandible with 6 minute recurved teeth. Maxilla with two setae of unequal length on inner ramus and three (one large and two small) on outer ramus. Terminal claw of first maxilliped beset with extremely fine acicular spines except on convex margin. Basal joint of second maxilliped stout, provided on the proximal ventral margin with two pads of different size and shape which are covered all over with acicular spinelets; the smaller pad lies just lateral to the regular basal seta partly encircling it; the larger lies proximal to the smaller with the narrower end in contact with the latter. Terminal claw of second maxilliped smooth, with an accessory spine at its base. Basipod of first leg covered with acicular hairs on outer side; endopod rod-shaped, beset on ventral side with extremely small spines, tipped with spine a little shorter than itself; exopod palm-shaped, covered ventrally with minute spines, with 5 short spines along its distal margin. Second leg one-jointed; both rami like those of first leg, though the marginal spines of the exopod show a tendency toward atrophy, the medial three being in the form of pointed teeth. Third leg removed far behind the second, extending diagonally outward and backward in form of an auricular lobe. Fourth leg one-jointed, bifurcate, directed backward; stem $0.62-0.85 \mathrm{~mm}$ long, both rami cigar-shaped, projecting well beyond posterior margin of dorsal plate, each provided at its tip with a small rounded knob covered with some twenty spines; endopod $1.1-1.5 \mathrm{~mm}$ long by $0.23-0.3 \mathrm{~mm}$ broad, may be unusually short; exopod $0.8-1.1 \mathrm{~mm}$ long by $0.2-0.28 \mathrm{~mm}$ broad. Fifth leg reduced to a short simple rod projecting outward and backward with its tip overlapping stem of fourth leg dorsally.

Male. Body length $1.9-2.0 \mathrm{~mm}$. Cephalothorax more rounded in outline than that of female, broader than the rest of the body, $0.55-0.63 \times 0.55-0.6 \mathrm{~mm}$. First thoracic segment completely fused with head. Second thoracic segment $0.22-0.3 \times 0.42$ $-0.5 \mathrm{~mm}$, third segment $0.37-0.4 \times 0.47-0.55 \mathrm{~m}$, fourth segment $0.37-0.5 \times 0.45-0.5 \mathrm{~mm}$, fifth (genital) segment and abdomen tapering rapidly toward caudal end. Caudal rami horn-shaped, divergent, arising just in front of anus, $0.12-0.14 \mathrm{~mm}$ long.

Appendages of male. First antenna like that of female. Second antenna with stout conical tooth medially as in female, terminal claw longitudinally striated but not granulated on convex side. Mandible and maxilla like those of female. Terminal law of first maxilliped with two marginal rows of minute spines. Second maxilliped, first and second legs as in female. Third leg bifurcated to near its base, both rami unequal in length, directed divergently outward and backward, with spiny terminal knob; exopod $0.3-0.5 \mathrm{~mm}$ long, endopod $0.15-0.2 \mathrm{~mm}$ long. Fourth leg bifurcate, entirely visible in dorsal view; stem $0.35-0.4 \mathrm{~mm}$ long, rami flattened cigar-shaped, 
varying in length with spiny terminal knob, divergent; exopod $0.37-0.45 \mathrm{~mm}$ long, endopod $0.36-0.58 \mathrm{~mm}$ long. Fifth leg lacking.

This species differs from the most closely related Lernanthropus micropterygis RICHIARDI of WILSON as shown in the following table of comparison.

\section{L. micropterygis L. latis of WILSON}

Body length

3.25 (male)

7.0 (female)

Caudal rami of female

attached to abdomen ventrally, lanceolate

Egg strings

Mandible

Fourth leg

of both sexes

Fifth leg

of female
$7 \mathrm{~mm}$ long

four-spined

divided to its base

lanceolate, reaching nearly to posterior margin of dorsal plate

\author{
1.9-2.0 (male) \\ 4.2-4.6 (female) \\ attached to abdomen \\ terminally, horn-like \\ 2-4 $\mathrm{mm}$ long \\ six-toothed \\ divided, but not to its base \\ rod-shaped, very short, \\ reaching to dorsal side of \\ stem of fourth leg
}

\section{Lernanthropus caesionis n. sp.}

(Pl. V, Figs. 49-52)

Habitat and locality. Gill of Caesio kuning (CUV. et VALENC.); Macassar, Celebes.

Material. Two mature females.

Female. Body (from anterior end of frontal plate to posterior end of dorsal plate) $3.1-3.3 \mathrm{~mm}$ long, enlarged posteriorly. Cephalothorax approximately trapezoid in dorsal view, though convex at posterior margin, $1.05-1.15 \times 0.85-0.98 \mathrm{~mm}$, with a prominent semicircular plate in front and the sides turned over ventrally. First thoracic segment fused completely with head, second thoracic segment fused with third segment to form a shoulder for the latter, which is broader than long with its greatest diameter $(0.9-1.25 \mathrm{~mm})$ at base of third legs, well marked off in front as well as behind. Dorsal plate circular, $1.47-1.58 \times 1.65-1.7 \mathrm{~mm}$, covering up entire fourth and fifth thoracic segments, abdomen, caudal rami and folded egg strings. Abdomen shorter and narrower than genital segment, at about center of dorsal plate. Caudal rami arising from ventral side of abdomen near its posterior end, lanceolate, a little longer than wide, with 2 minute hairs at the tip. Egg strings folded up under dorsal plate, about $1.5 \mathrm{~mm}$ long, each containing a series of some 40 discoid eggs.

Appendages. First antenna arising from ventral side of front plate near its lateral margin, unsegmented, showing a more or less sharp bending on anterior 
margin a little proximal to its middle, whence it tapers rapidly toward the setose tip. Terminal claw of second antenna with longitudinal striations. About midway between the base of the first antenna and that of the second antenna there is a long setiform antennule containing pulp throughout its length. Behind the second antenna lies a blunt-pointed rod-shaped process slightly curved outward and backward. Mandible with 7 small recurved teeth. Inner ramus of maxilla with a single terminal seta, outer ramus tipped with 2 unequal setae. Terminal claw of first maxilliped distinctly pectinate; that of second maxilliped longitudinally striated. Exopod of first leg palmshaped, with 5 terminal spines, endopod short, rod-shaped, smooth. Exopod of second leg with three short spines and two much smaller ones, endopod small, stumpy, without setae. Third leg laminate, folded, projecting downwards perpendicularly. Fourth leg divided to near its base, both rami markedly attenuated posteriorly, subequal $(1.0-1.15 \times 0.21-0.3 \mathrm{~mm})$, the inner slightly longer than the outer with their tips projecting a short distance beyond posterior border of dorsal plate. Fifth leg lacking.

This species differs from Lernanthropus pristipomodis KIRTISINGIE, 1937, in general appearance, especially in the dorsal plate being distinctly separated from the foregoing thoracic segment, in the first antennae being unsegmented, and in the fourth leg being much narrower posteriorly and projecting backward but little beyond the dorsal plate.

\section{DICHELESTHIIDAE}

\section{Hatschekia teuthidis n. sp.}

(P1. VI, Figs. 53-55)

Habitat and locality. Gill of Teuthis sp.; Maccasar, Celebes.

Material: Three mature females without egg sacs.

Female. Body 0.94-1.05 mm long. Head rounded, $0.13-0.15 \times 0.13-0.19 \mathrm{~mm}$ with strongly convex sides and prominent medially notched frontal plate; dorsal chitinous frame consisting of a pair of symmetrical arcuate lateral arms, with a pair of ventrally recurved accessory pieces inside of their anterior half, and a median rib, whose anterior end extending into the frontal plate forms an elliptical ring, and whose posterior end forms a sharp-pointed dagger. A blunt-conical knob is present immediately behind the base of each second antenna, but none on either side of the base of the mouth tube. First thoracic segment forming neck $0.12 \mathrm{~mm}$ broad, second fused with genital segment. Latter elongated elliptical, though constricted at middle, $0.69-0.75 \mathrm{~mm}$ long by $0.23-0.25 \mathrm{~mm}$ broad. Abdomen small, semicircular, with prominent anal region. Caudal rami rod-shaped, $24 \mu$ long by $10 \mu$ broad, attached to ventral 
side of abdomen, with an acicular seta on outer margin and five setae at distal end.

Appendages. First antenna not segmented, about $0.1 \mathrm{~mm}$ long, projecting outward a little beyond lateral margin of head, with comparatively few setae on ventral side, tipped with 7 setae, one of which being very fine may be overlooked. Basal segment of second antenna constricted near its distal end; terminal claw comparatively small, strongly recurved. Maxilla represented by a spiniform seta. Mandible slender, without teeth on its small cutting blade. Maxilliped 4-segmented; terminal claw bifid at tip; third segment slender, shorter than second segment. First two pairs of legs biramose ; exopod distinctly, endopods indistinctly, 2-segmented. Proximal segment of first exopod with a very minute seta at outer distal end; distal segment of first exopod with one subterminal and three terminal setae in the type, but like that of second exopod in the paratypes. First endopod narrower than second endopod, tipped with one to three setae. ${ }^{1)}$ Proximal segment of second exopod with a terminal seta a little shorter than distal segment; latter with a very fine seta besides the terminal one; endopod with one subterminal and three terminal setae. Third leg on ventrolateral margin of trunk, $0.55 \mathrm{~mm}$ behind second leg, represented by a hair-like seta with a papilliform base. It was found on the right side only in the type, but not in the paratype. Fourth leg lacking.

This species resembles Hatschekia labracis (VAN EENEDEN) of mine (1939) very closely, but differs from it in the dorsal chitin-frame of the head, and the appendages, especially in the first antenna being unsegmented, in the maxilla consisting of one seta and one spine without being divided into 2 setiferous lobes, and in the swimming legs being more poorly developed.

\section{Hatschekia synagris n. sp.}

(P1. VI, Figs. 56-58)

Habitat and locality. Gill of Synagris taeniopterus (VALENC.); Macassar, Celebes.

Material. Two mature females with egg sacs detached.

Female. Body 1.0-1.025 mm long. Head nearly quadrangular, though semicircular or broadly rounded at posterior margin, $0.22-0.23 \mathrm{~mm}$ long by $0.21-0.23 \mathrm{~mm}$ broad; frontal plate cordate, 2-lobed, with median notch. Dorsal chitinous framework consisting of a very strong transverse bar and a median rib, the anterior end of which is expanded into a triangular plate and lies in the frontal plate with the flat basis in front. On either side of the head just behind the second antenna there are

1) Even in the same individual the number of the setae is different on the right and left. In the type the right endopod terminates in a relatively strong seta, the left one however bears three small setae. 
close together two short horn-like processes with their tips directed outward. At this level the head attains its maximum diameter. First thoracic segment constricted off from head and covered up dorsally by its posterior lobe. Second thoracic segment fused with genital segment. Latter elliptical, $0.65-0.68 \times 0.25-0.325 \mathrm{~mm}$. Abdomen small, inverted trapezoid, $42 \times 60 \mu$ in the type. Caudal rami rod-shaped, $33-36 \times 13-15 \mu$, with one seta on dorsolateral margin and three setae at tip.

Appendages. First antenna not segmented, $0.18 \mathrm{~mm}$ long, with 16 setae on anterior margin, about a dozen setae at tip. Second antenna stout, with strongly curved claw. Maxilla divided to near its base into two setae of unequal length, of which the inner one is a little longer. Mandible in form of a slender cutting knife. Maxilliped 4-segmented; third segment slender, just as long as second segment; terminal claw bifid at tip.

First and second legs biramose; each exopod 2-segmented, endopod of first leg not segmented, but of second leg 2-segmented. Proximal segment of first exopod with a rudimentary seta at outer distal end, distal segment tipped with two setae; endopod with two terminal setae. Proximal segment of second exopod produced backward beyond base of distal segment and bearing a very long seta, distal segment with a minute seta besides the much longer one at tip; endopod tipped with two setae. Third leg lacking, or rudimentary if at all.

This species is characterized by the almost quadrangular shape of the head, the structure of the dorsal chitinous framework, etc. Hatschekia foliata REDKAR, RANGNEKAR et MURTI; 1950, from the related Synagris japonica is easily distinguished from the present species by its general body shape, especially by the marginal indentations of the genital segment.

\section{Hatschekia longigenitalis n. sp.}

$$
\text { (Pl. VI, Figs. 59-61) }
$$

Habitat and locality. Gill of Synagris taeniopterus (VALENC.); Macassar, Celebes. Material. Some ten mature females.

Female. Body slender, $1.0-1.3 \mathrm{~mm}$ long. Head rounded, $0.1-0.11 \mathrm{~mm}$ long by $0.13-0.17 \mathrm{~mm}$ broad, with the sides projecting in form of a hemisphere; frontal margin depressed; posterior margin broadly rounded, overlapping first thoracic segment, with a slight notch between itself and the knob-like side. Dorsal chitinous framework consisting of a median piece and a pair of arcuate lateral arms making altogether a farmer's three-pronged raker withont handle. On the ventral side just anterolateral to each maxilla there is a two-tipped nodular process projecting ventrad. First thoracic segment forming neck at level of base of its legs. Second thoracic segment fused 
with genital segment to form a trunk, which is very long and slender, constituting the most outstanding feature of this parasite. Genital segment $0.9-1.128 \mathrm{~mm}$ in length, $0.14-0.18 \mathrm{~mm}$ in maximum width near its posterior end. Abdomen hemispherical, 15-25 $\mu$ long by $30-50 \mu$ broad, with more or less prominent anal region. Caudal rami rod-shaped, $15-21 \times 6-9 \mu$, with one seta on dorsolateral margin, another subterminally and three more terminally.

Appendages. First antenna not segmented, though the somewhat broader proximal portion bearing a row of 4 setae along its anteroventral margin may be marked off from the rest by an abrupt rise on the anterior margin; provided with comparatively few setae (about 10 along anterior margin, 6 setae at and near tip). Second antennae abruptly enlarged at base, projecting forward close together with their small terminal claws directed ventrad. Maxilla divided into two lobes, each of which bears two setae. Mandible slender, without teeth. Maxilliped 4-segmented, third segment a little shorter than second; terminal claw bifid at tip. First and second legs biramose; exopods of both legs two-segmented, but endopods one-segmented. Proximal segments of both exopods with one seta each, distal segment with three setae for first leg and two for second leg; both endopods with one seta on inner margin and three at tip. Third legs lacking.

This species resembles Hatschekia pagrosomi YAMAGUTI, 1939, in the extraordinary length of the genital segment, but differs from it in body size, in the head being much more produced outward, in the endopods of the first two swimming legs being unsegmented, etc.

\section{Hatschekia gracilis n. sp.}

(P1. VI, Figs. 62-65)

Habitat and locality. Gill of Lethrinus sp.; Macassar, Celebes.

Material. Some ten mature females.

Female. Body slender, $1.9-2.1 \mathrm{~mm}$ long. Head cordate, $0.175-0.2 \mathrm{~mm}$ in length, $0.16-0.19 \mathrm{~mm}$ in maximum breadth near posterior margin which is only slightly convex and partly covers the first thoracic segment. Frontal plate prominent, flattened conical or semicircular, projecting a little beyond the bases of first antennae. Dorsal chitinous framework consisting of a pair of symmetrical arcuate lateral arms and a median rib, the anterior end of which extends into the frontal plate and forms a triangle. Each of the two arms is supported near its anterior end by an X-shaped accessory piece, whose ventrally directed stem turns inward at the point where it gives rise to a rudimentary side branch. The median rib as well as the two arms terminates in a sharp point at the level of the broadest part of the head. On the ventral side of the head just behind the base of each second antenna there is a fleshy, not very sharp- 
pointed process applied to the antenna. First thoracic segment forming neck only $90 \mu$ broad. Genital segment slender, $1.6-1.8 \mathrm{~mm}$ in length, $0.18-0.2 \mathrm{~mm}$ in maximum breadth at its posterior third. Abdomen semicircular, $18-24 \mu$ by $50-63 \mu$. Caudal rami small, $15-18 \times 7-8 \mu$, attached to ventral side of abdomen. : Egg sacs cigaretteshaped, $0.62-0.95 \mathrm{~mm}$ long, each containing a series of about ten or more eggs.

Appendages. First antenna 84-90 $\mu$ long, tapering gradually toward distal end, without distinct joints except the basal which occupies almost half the entire length. The marginal setae of the first antenna are very fine and few (only 5 for the basal segment); of the 8 terminal ones five are longer than the others which are minute like the marginal. Stout basal segment of second antenna finely dotted on the surface for the greater part; terminal claw falcate. Maxilla represented by a simple seta. Mandible slender, without teeth. Maxilliped 4-segmented; third segment a little shorter than second segment; terminal claw bifid. First and second legs biramose; exopods 2segmented but endopods 1-segmented. Proximal segments of first and second exopods with a terminal spine at each distal outer end. Distal segment of first exopod with 5 setae, of which two are at the tip, and the other three along distal inner margin; first endopod with 5 setae including the one at middle of inner margin. Second exopod with three terminal setae; second endopod with two setae on inner margin and four at tip. Third legs absent.

This species differs from the most closely related $H$. longigenitalis (vide supra) chiefly in body size, the shape of the head and the structure of its chitinous framework, in the second antennae being dotted for the greater part and in the maxilla being a simple seta.

\section{LITERATURE}

VAN BENEDEN, P. J. 1871. Les poissons des côtes de Belgique, leur parasites et leur commenseaux. Mem. Acad. Roy. Soc. Belg., vol. 38, 100 pp.

KIRTISINGHe, P. 1937. Parasitic copepods of fish from Ceylon. II. Parasit., vol. 29, pp. 450-452. REDKAR, M., RANGNETAR, P. G. and MURTI, N. N. 1949. Four new species of parasitic copepods from the marine fishes of Bombay. Jour. Univ. Bombay, vol. 18, no. 3, pp. 35-50.

WILsON, C. B. 1905.' North American parasitic copepods belonging to the family Caligidae. Proc. U. S. Nat. Mus., vol. 28, pp. 479-672.

1913. Crustacean parasites of West Indian fishes and land crabs, with descriptions of new genera and species. Ibid., vol. 44, pp. 189-277.

1928. Parasitic copepods from the White Nile and the Red Sea. Results of the Swedish Zool. Exped. to Egypt and the White Nile, 1901. Part 5, pp. 1-17.

YAMAguti, S. 1936. Parasitic copepods from fishes of Japan. Part 2. Caligoida, I. Published by the author. Kyoto. 22 pp. 


\section{ExPLANATion OF PLATES}

Plate I

Figs. 1-7. Female of Ergasilus borneoensis n. sp.

Fig. 1. Dorsal view of gravid female.

Fig. 2. Mouth parts.

Fig. 3. First leg.

Fig. 4. Second leg.

Fig. 5. Third leg.

Fig. 6. Fourth leg.

Fig. 7. Fifth leg.

Figs. 8-10. Female of Taeniacanthus upenei n. sp.

Fig. 8. Dorsal view of gravid female. Fig. 9. Mouth parts.

Fig. 10. Fifth leg.

\section{Plate II}

Figs. 11-16. Female of Taeniacanthus upenei n. sp.

Fig. 11. Posterior extremity.

Fig. 12. Antenna and maxillary hook.

Fig. 13. First leg.

Fig. 14. Second leg.

Fig. 15. Third leg.

Fig. 16. Fourth leg.

Figs. 17-18. Female of Taeniacanthus upenei upeneoides $n$. subsp.

Fig. 17. Chitinous median structure on ventral side of cephalothorax in front of base of first legs.

Fig. 18. Fifth leg.

Fig. 19. Mature male of Caligus alalongae (KRÖYER, 1863).

Plate III

Fig. 20. Chitinous median structure on ventral side of cephalothorax in front of base of first legs in female of Taeniacanthus upenei n. sp.

Fig. 21. Gravid female of Caligus alalongae (KRöYER, 1863)

Figs. 22-25. Female of Caligus grandiabdominalis n. sp.

Fig. 22. Dorsal view of mature female.

Fig. 24. Third leg.

Figs. 26-27 Female of Caligus paxillifer n. sp.

Fig. 26. Dorsal view of a mature female. Fig. 27. First leg.
Fig. 23. Second leg.

Fig. 25. Fourth leg.

\section{Plate IV}

Figs. 28-32. Female of Caligus paxillifer n. sp.

Fig. 28, Maxillary hook.

Fig. 29. Furca.

Fig. 30. Second leg.

Fig. 31. Third leg.

Fig. 32. Fourth leg.

Figs. 33-34. Female of Caligus annularis n. sp.

Fig. 33. Dorsal view of mature female.

Fig. 34. Furca. 
Figs. 35-39. Female of Lernanthropus corniger n. sp.

Fig. 35. Dorsal view of mature female.

Fig. 36. Second antenna.

Fig. 37. Maxilla.

Fig. 38. First maxilliped.

Fig. 39. Second maxilliped.

\section{Plate V}

Figs. 40-41. Female of Lernanthropus corniger n. sp.

Fig. 40. First leg.

Fig. 41. Second leg.

Figs. 42-46. Female of Lernanthropus latis n. sp.

Fig. 42. Dorsal view of gravid female.

Fig. 43. Ventral view of posterior extremity.

Fig. 44. Second antenna.

Fig. 45. First leg.

Fgi. 46. Second leg.

Figs. 47-48. Male of Lernanthropus latis n. sp.

Fig. 47. Dorsal view of mature male.

Fig. 48. First maxilliped.

Figs. 49-52. Female of Lernanthropus caesionis n. sp.

Fig. 49. Dorsal view of mature female.

Fig. 50. First and second maxillipeds and first leg.

Fig. 51. Second leg. Fig. 52. Caudal rami and fourth leg.

\section{Plate VI}

Figs. 53-55. Female of Hatschekia teuthidis n. sp.

Fig. 53. Dorsal view of mature female. Fig. 54. Antenna.

Fig. 55. Second leg.

Figs. 56-58. Female of Hatschekia synagris n. sp.

Fig. 56. Dorsal view of mature female. Fig. 57. First leg.

Fig. 58. Second leg.

Figs. 59-61. Female of Hatschekia longigenitalis n. sp.

Fig. 59. Dorsal view of mature female. Fig. 60. First leg.

Fig. 61. Second leg.

Figs. 62-65. Female of Hatschekia gracilis n. sp.

Fig. 62. Dorsal view of gravid female.

Fig. 63. Second antenna.

Fig. 64. First leg.

Fig. 65. Second leg. 


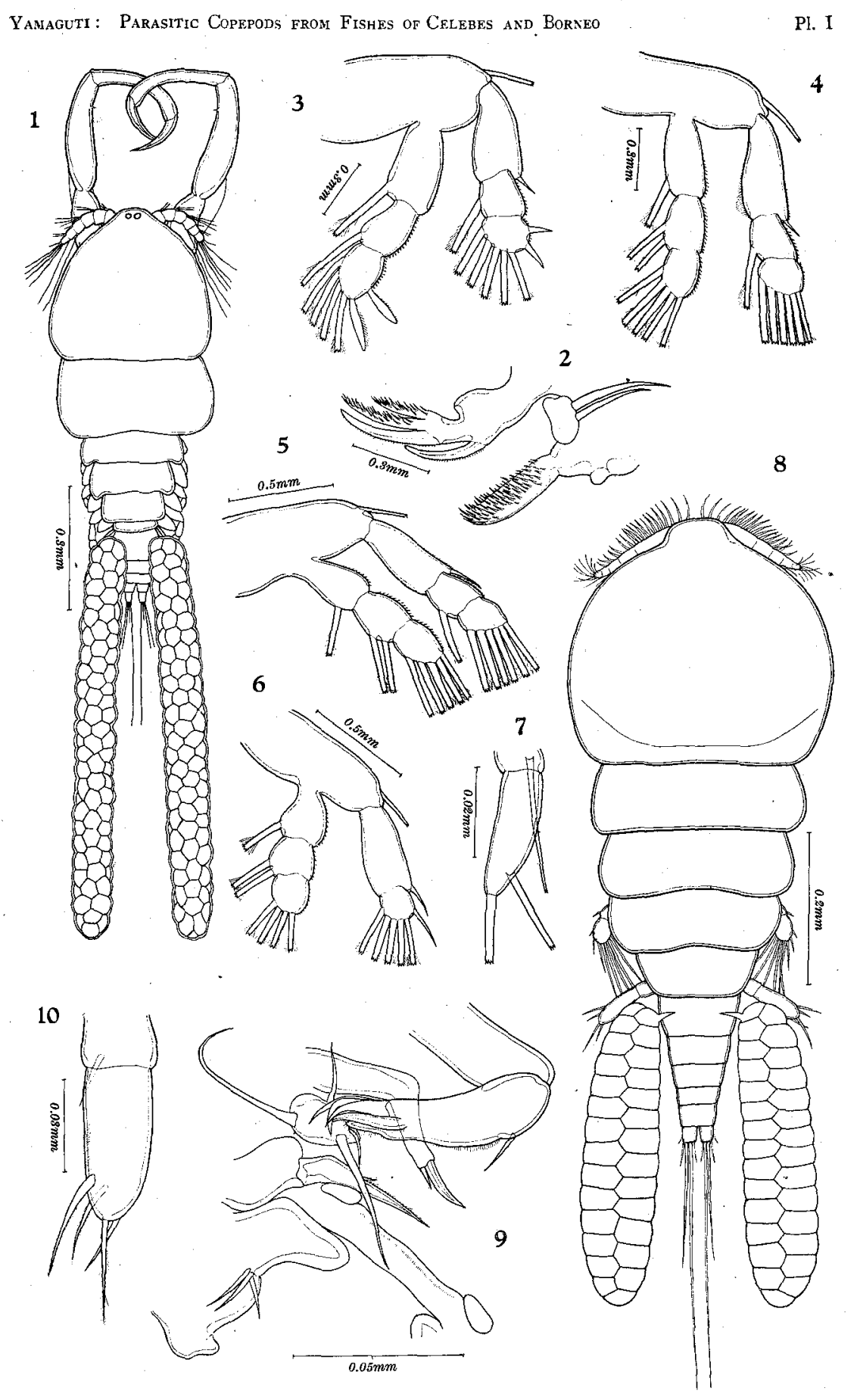


Yamaguti: Parasitic Cophopos from Fishes of Celebes' and Borneo

Pl. II

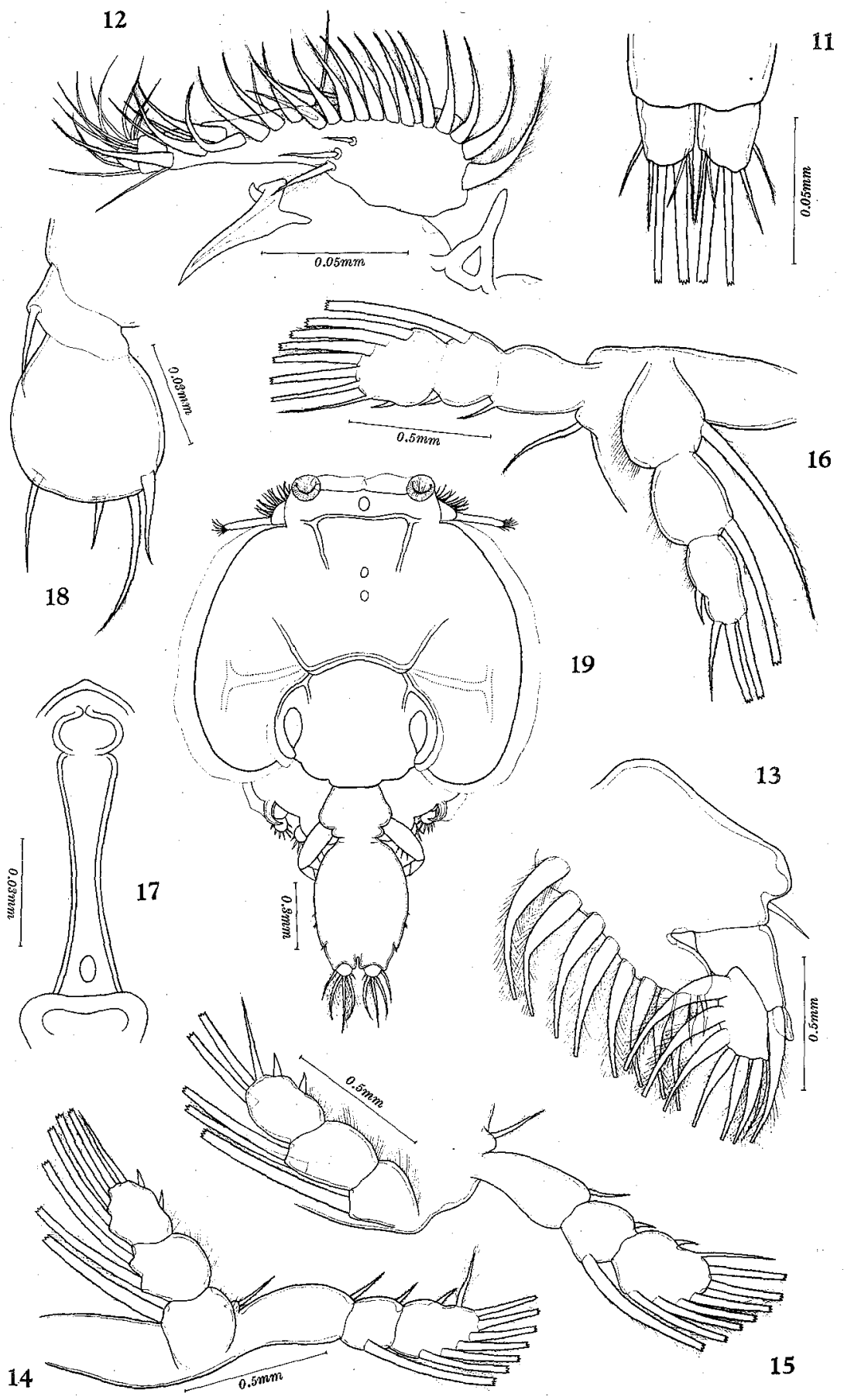


Yamaguty: Parasitic Copepons from Fishes of Chlebes and Borkeo

PI. III

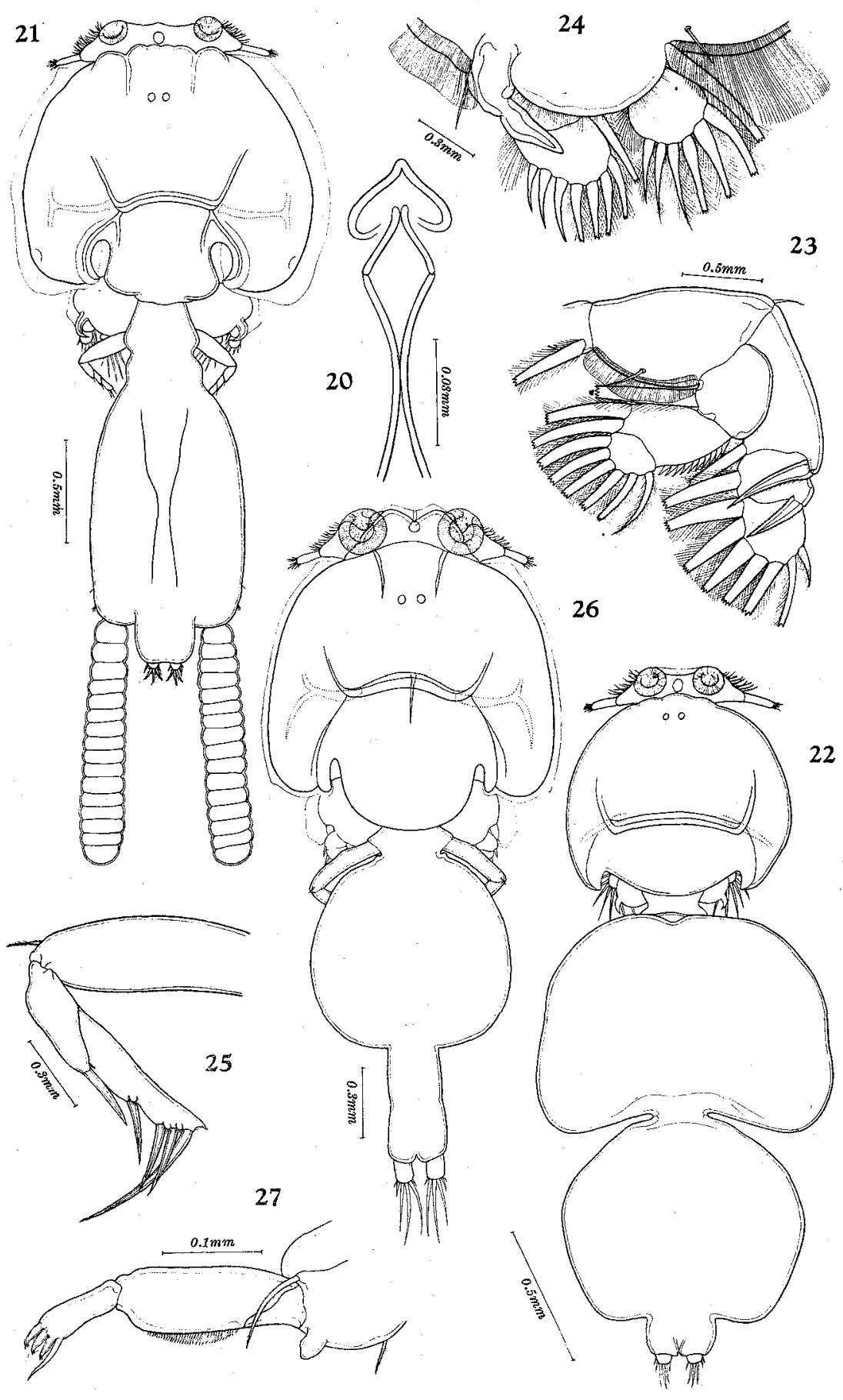



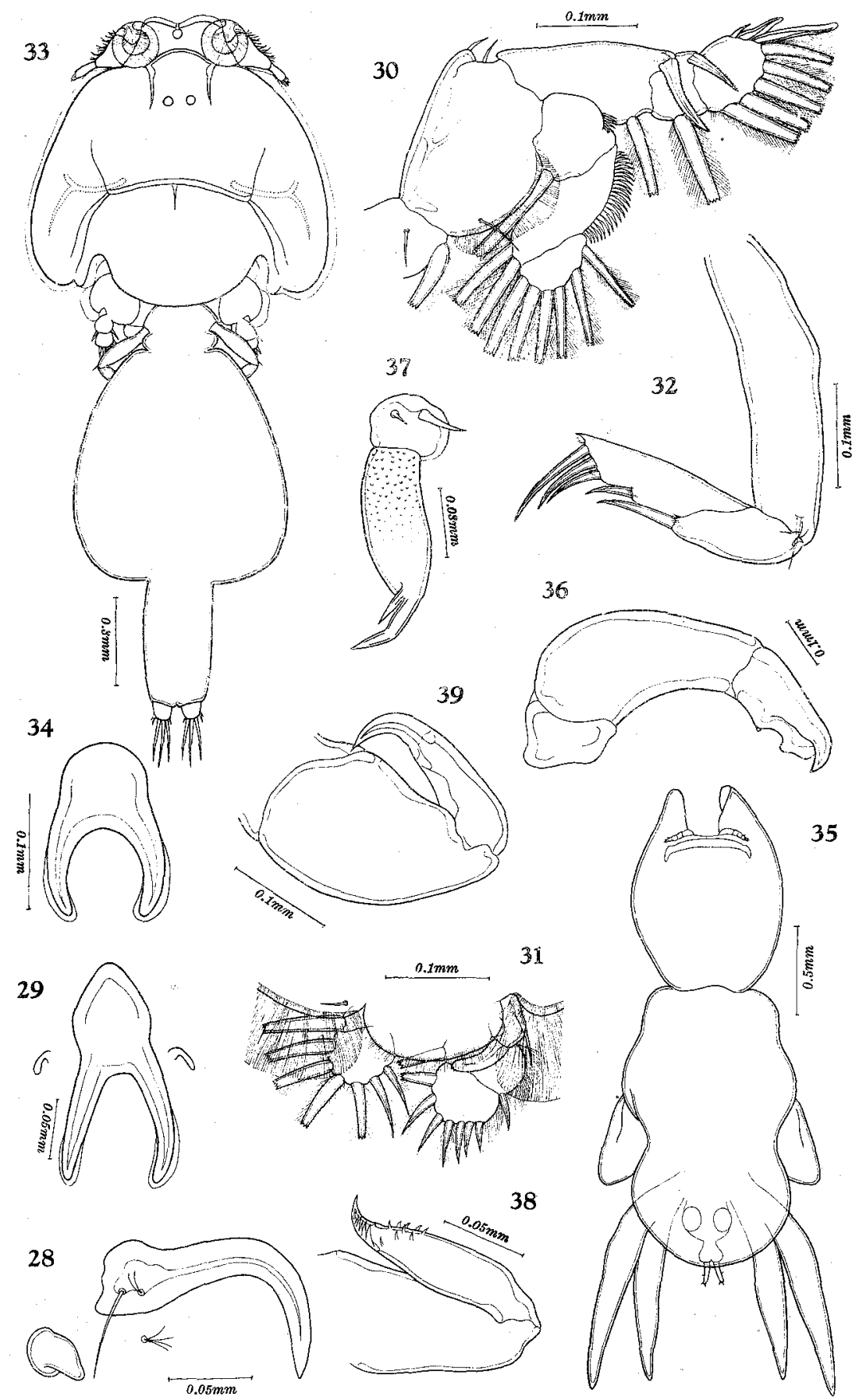


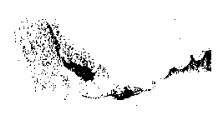

Yamaguti: Parasitic Copepods from Fishes of Celebes and Borneo

Pl. V

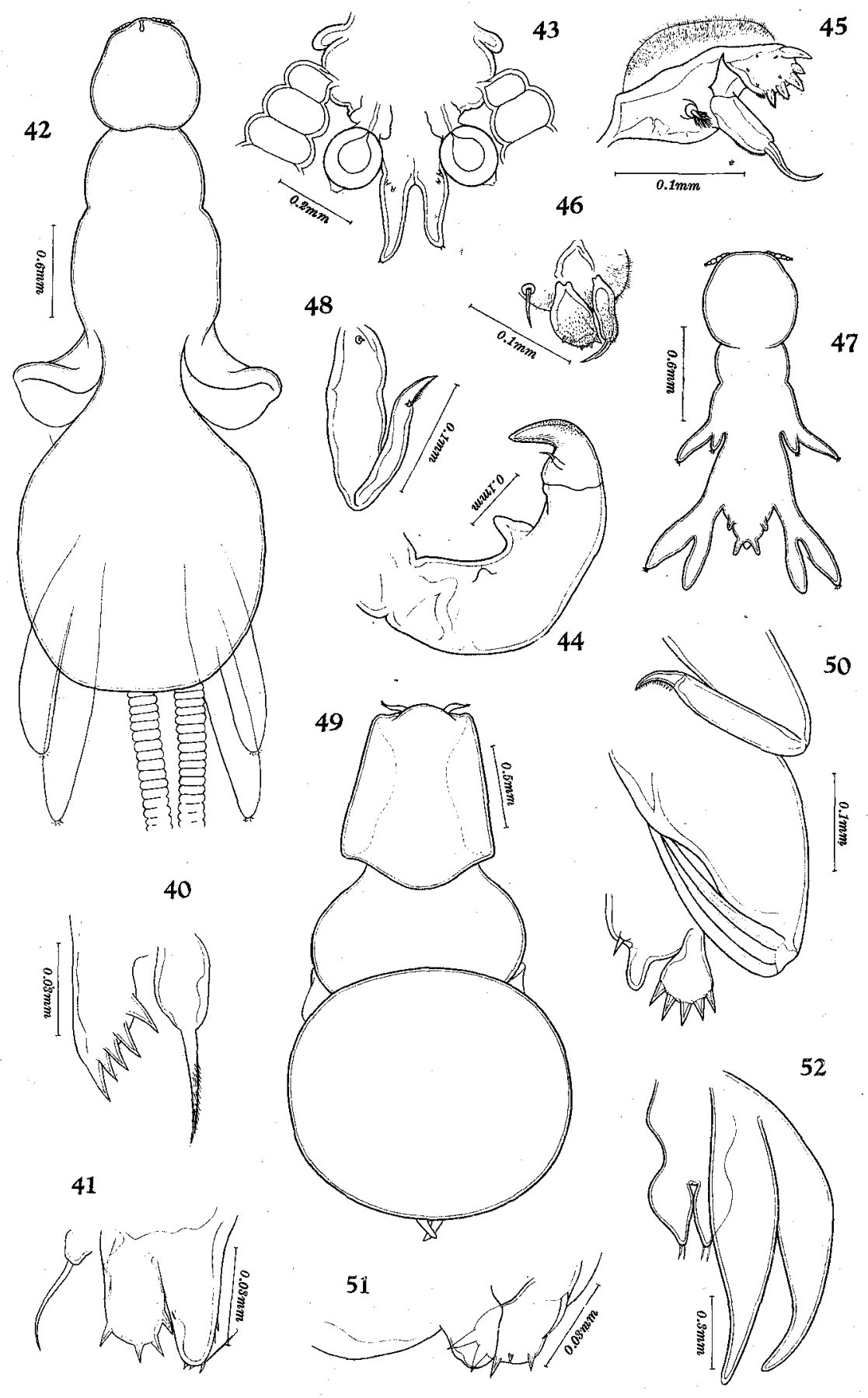


Yamaguti : Parasitic Copepons from Fishes of Celebes and Borneo

Pl. VI
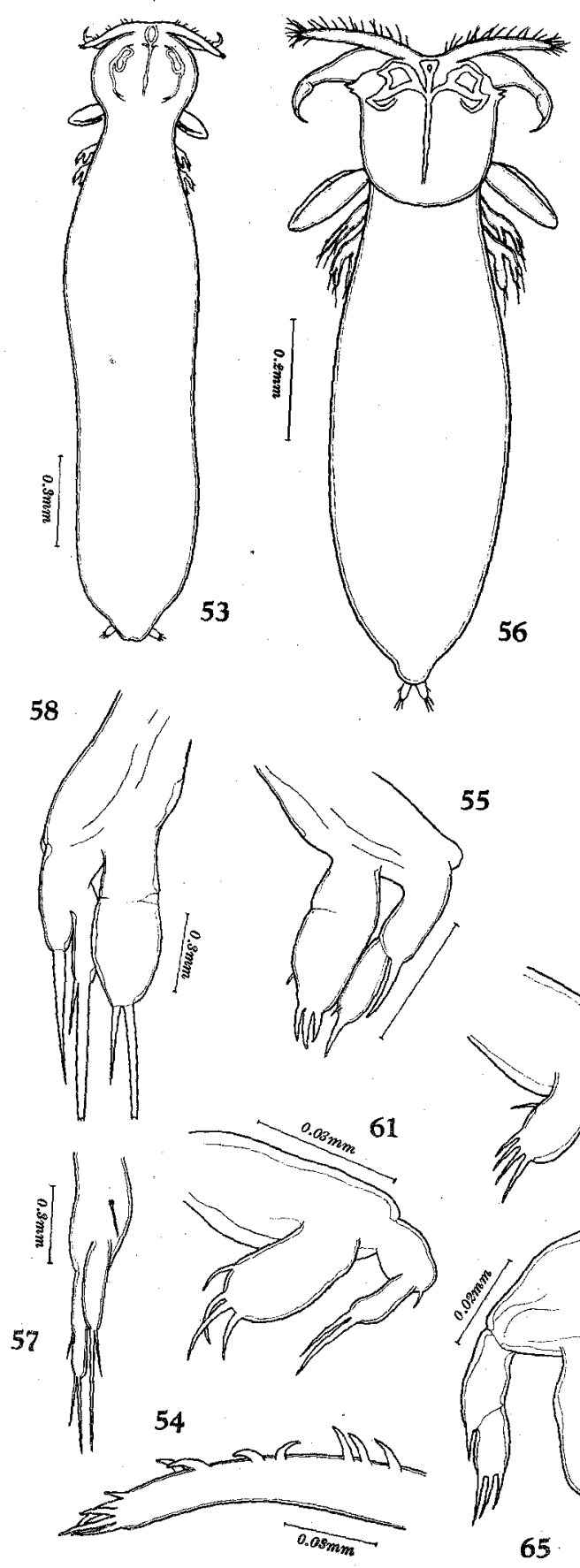

55
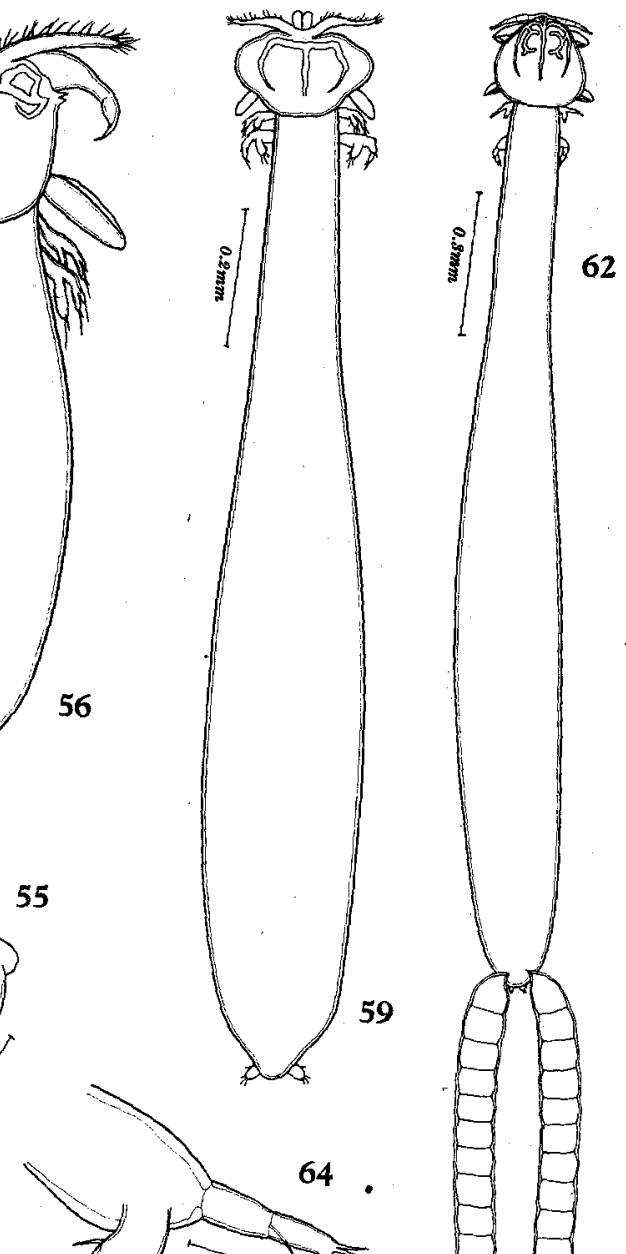

62

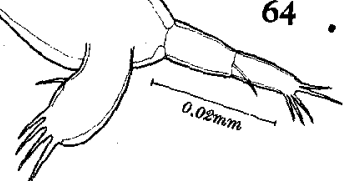

59
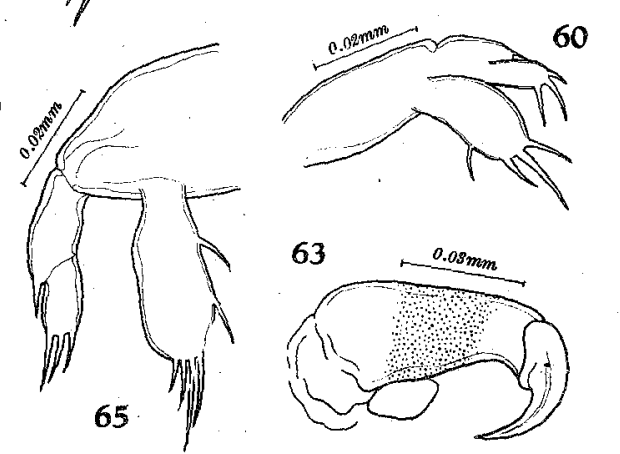